\title{
Effect of Micro-Remediation on Enzymes Activity and Available Nutrients in Chlorpyrifos-Polluted Soils
}

\author{
Junhua $\mathrm{Wu}^{1}$, Xin $\mathrm{Chen}^{1}$, Chuanzhou Ou ${ }^{1}$, Chunping Huang ${ }^{1,2, *}$ \\ ${ }^{1}$ College of Life Sciences, Sichuan Normal University, Chengdu, China \\ ${ }^{2}$ Sichuan Engineering Center for Farmland Ecosystem Service Capacity Construction, Institute of Agro-products Processing, Chengdu, China
}

Email address:

15708435942@163.com (Junhua Wu),719176668@qq.com (Xin Chen), 1349529424@qq.com (Chuanzhou Ou), 18215115@qq.com (Chunping Huang)

${ }^{*}$ Corresponding author

To cite this article:

Junhua Wu, Xin Chen, Chuanzhou Ou, Chunping Huang. Effect of Micro-Remediation on Enzymes Activity and Available Nutrients in Chlorpyrifos-Polluted Soils. Agriculture, Forestry and Fisheries. Vol. 6, No. 5, 2017, pp. 166-172. doi: 10.11648/j.aff.20170605.14

Received: June 22, 2017; Accepted: July 3, 2017; Published: September 22, 2017

\begin{abstract}
In order to find out the effect of micro-remediation on enzyme activity and available nutrient in chlorpyrifos-polluted soils and the correlation of enzyme activity, available nutrients and chlorpyri fos residue during soil remediation process, the soils planting Brassica juncea throughout the year, sprayed with chlorpyrifos and treated with bacteria were selected as restoration land, while the soils only sprayed with chlorpyrifos were regarded as reference land. The results showed that the activities of urease, catalase, amylase and phosphatase in the restoration land were higher than those in the reference land, especially in the subsequent phase of sample time $(P<0.05)$. Correlation analysis demonstrated that there was significantly negative correlation between amylase activity and chlorpyrifos residue in the soils only sprayed chlorpyrifos, while amylase and catalase activity had a significantly negative correlation with chlorpyrifos residue respectively in the restoration soils $(P<0.01)$. Meanwhile, just as the soil enzyme activities, the available nutrients content in the restoration soils were higher than those in the soils only sprayed chlorpyrifos, and significant difference for available phosphorus between the two soils $(P<$ 0.05 ) can be observed. Correlation analysis demonstrated that there was no significant correlation between available nutrients and chlorpyrifos residue in the reference soils, while available phosphorus content was significantly negatively correlated with chlorpyrifos residue in the restoration soils $(P<0.01)$. In general, the microbial remediation can contribute to effectively enhancing the contents of available nitrogen, available potassium and available phosphorus in soils polluted by chlorpyrifos and improve soil fertility well.
\end{abstract}

Keywords: Micro-Remediation, Chlorpyrifos, Soil Enzymes Activity, Soil Available Nutrients

\section{Introduction}

Chlorpyrifos, an organophosphorus pesticide, is used extensively all over the world [1]. With the increasing application of Chlorpyrifos, the content of it in soils increases constantly by different ways. Therefore, it brings more and more serious threats to soil ecosystem and leads to an obvious environmental contamination problem [2,3]. The remediation strategy of microbial degradation based on biological remediation theory, being highly effective and environment-friendly, is one of important methods in decomposing pesticide residue in agricultural products and environment [4, 5]. But whatever methods are took to remediate polluted soil, it is a long and complex process to make the soil restore primitive condition and functions. So scientifically and overall investigating and estimating the health of soil and the soil-remediated processes exhibit an essential implication in ecology [6].

Soil is a system in which a variety of complex biochemical processes take place in demand of enzymes. Soil enzymes, mainly produced by microbes, the root of plants and animals, are proteins that decompose organic matter in soil. Soil enzymes participate in the whole organic matter transformation period, and have a direct or indirect influence on a series of biochemical reactions $[7,8]$. The activity of soil enzymes indicates the degree of soil metabolism, soil fertility and the quality of soil environment, and gradually becomes an 
important research direction in soil environmental quality monitoring [9]. It is also a useful indicator to estimate the process of remediation in pesticide-polluted soil [10-12].

In the former experiment, a bacterial strain that can degrade Chlorpyrifos effectively was obtained by screening, and it had a high effectivity of degrading Chlorpyrifos in Brassica juncea and its growing soil [13]. With soil enzymes (urease, catalase, amylase and phosphatase) and available nutrients being assay indices of this study, soils quality change was investigated during Chlorpyrifos bio-remediated process in Brassica juncea growing soil. In addition, the correlation analysis between Chlorpyrifos and soil enzymes, and between Chlorpyrifos and available nutrients were carried out to provide the theory basis for fully comprehending the process of bio-remediation in pesticide-polluted soils.

\section{Materials and Methods}

\subsection{Materials}

The test bacterial strain isolated from the laboratory was identified as Bacillus subtilis MZS1 (B. sub), and its accession number of 16S rDNA at GenBank was KJ882376. Brassica junceai which annually grew in Xindu experimental base of Sichuan Academy of Agricultural Sciences was choose as test plant. The test soils were purple soils in the experimental base, $\mathrm{pH} 6.5 \sim 6.6$, and soil organic matter was about $13.2 \mathrm{~g} / \mathrm{kg}$.

\subsection{Trials in the Field Soils}

Trials were conducted between the beginning of November
2014 and early February 2015 in Xindu experimental base where Brassica junceai annually grew. The trial field was sprayed with Chlorpyrifos $\left(60 \mathrm{~g} / \mathrm{hm}^{2}\right) 40$ days after planting Brassica junceai. Then the experimental group was sprayed with 5L MZS1 bacterium aqueous solution at the dose of 50 $\mathrm{L} / \mathrm{hm}^{2} 2$ days later in the trail field, while the control group was sprayed with $5 \mathrm{~L}$ sterile medium aqueous solution (50 $\mathrm{L} / \mathrm{hm}^{2}$ ). Field management was conducted as usual.

Soil samples were collected from a depth of $0.5-10 \mathrm{~cm}$ by soil auger on day 5, day 10 , and day 15 respectively after MZS1bacterium aqueous solution was sprayed, and each sample is of three replicates. All samples were carried back to laboratory in low temperature condition. Part of samples were stored in refrigerator at $-4^{\circ} \mathrm{C}$ for enzymes activity analyze, while the other part of samples in refrigerator at $-80^{\circ} \mathrm{C}$ were used for available nutrient analyze.

\section{Analytical Methods}

\subsection{Chlorpyrifos Analyses}

The content of Chlorpyrifos was analyzed by HPLC using the method described by Luo et al.[14], the chromatographic separation was performed with Alltech Apollo C18 column $(250 \mathrm{~mm} \times 4.6 \mathrm{~mm}, 5 \mu \mathrm{m})$ at $25^{\circ} \mathrm{C}$ with methanol $/ \mathrm{H}_{2} \mathrm{O}(85: 15$, $\mathrm{V}: \mathrm{V})$ gradient elution, waters 24787 detector, and Model 100 column oven. A sample injection volume of $10 \mu \mathrm{L}$, flow rate of $1 \mathrm{~mL} / \mathrm{min}$, and a detection wavelength: $230 \mathrm{~nm}$. The contents of Chlorpyrifos in different groups were showed in Table 1 .

Table 1. The chlorpyrifos contents in the soil at each sampling time.

\begin{tabular}{lll}
\hline Time $/($ Day $)$ & The control soil $/\left(\mathbf{m g ~ k g}^{-1}\right)$ & The remedied soil $/\left(\mathbf{m g ~ k g}^{-1}\right)$ \\
\hline 0 & $59.73 \pm 0.12^{\mathrm{aA}}$ & $59.68 \pm 0.24^{\mathrm{aA}}$ \\
5 & $56.62 \pm 2.03^{\mathrm{aAB}}$ & $50.02 \pm 0.90^{\mathrm{bB}}$ \\
10 & $53.67 \pm 0.21^{\mathrm{aBC}}$ & $41.48 \pm 0.49^{\mathrm{bC}}$ \\
15 & $50.65 \pm 2.13^{\mathrm{aC}}$ & $32.35 \pm 0.92^{\mathrm{bD}}$ \\
\hline
\end{tabular}

The remedied soil group is sprayed with MZS1 bacterium; the control group is sprayed with sterile medium. The values are mean \pm S. D. Small letters stand for differences between the remediated soil group and the control group at different time $(P<0.05)$. Capitals stand for differences between different groups at the same time $(P<0.05)$.

\subsection{Enzyme Activities Analyses}

The enzymatic activities were determined according to the method of Zheng and Zhang's [15]. Catalase activity was determined as $\mathrm{ml} \mathrm{KMnO}_{4}(0.01 \mathrm{~mol} / \mathrm{L})$ which was reacted $/ \mathrm{g}$ dried soil, urease activity expressed as $\mathrm{mg} \mathrm{NH}_{4} / \mathrm{g}$ dried soil during 24 hours, phosphatase activity expressed as $\mathrm{mg}$ fenol / $\mathrm{g}$ dried soil during 24 hours, and amylase activity determined as mg glucose / $\mathrm{g}$ dried soil during 24 hours.

\subsection{Available Nutrient Analyses}

The available nutrient in soil for assay was accorded with the method of Bao's [16]. Alkali -hydrolyzable nitrogen was assayed by alkali-diffusion method and expressed as mg alkali -hydrolyzable nitrogen / kg dried soil. Available phosphorus, extracted with $0.5 \mathrm{~mol} / \mathrm{L} \mathrm{NaHCO}_{3}$, was assayed by $\mathrm{Mo}-\mathrm{Sb}$ colorimetric method and determined as $\mathrm{mg}$ available phosphorus per $\mathrm{kg}$ dried soil. Available potassium was extracted with $1 \mathrm{~mol} / \mathrm{L} \mathrm{NH}_{4} \mathrm{OAc}$ for being measured by atomic absorption spectroscopy, and it was expressed as mg available potassium per $\mathrm{kg}$ dried soil.

\subsection{Statistical Analysis}

All date were expressed as mean \pm standard deviation (mean $\pm \mathrm{SD}$ ) with 3 replications. Graphic processing took use of Excel soft. Results were statistically and correlatively analyzed using SPSS version 18.0 statistical software, and assessed using the lowest standard deviation (LSD) test $(\mathrm{p}=$ $0.05)$. 


\section{Results and Discussion}

\subsection{Enzymes activity Change in Different Remediative Period}

Urease, a kind of amidase, is a unique soil enzyme to catalyze the hydrolysis of urea. So it becomes an indicator of microbial activity and soils quality. Urease has a unique effect on nitrogen cycle. Its enhanced activity may contribute to catalyzing relatively stable organic nitrogen into available nitrogen, furtherly enlarge the quantity of nitrogen in soils [17]. As showed in Figure 1 (I), Urease activity decreased in soils sprayed with only chlorpyrifos during a short period. With Brassica junceai growing, Urease activity increased gradually. And urease activity did not basically restore to original level until Brassica junceai was harvested. It was indicated that Urease activity showed negative correlation with chlorpyrifos to some extent. But the difference was not significant $(P>0.05)$ (Table 2). Urease activity increased gradually in soils sprayed with bacterial solution, and there was unobviously negative correlation between it and chlorpyrifos $(P>0.05)$. In addition, urease activity was significantly higher in soils sprayed with bacterial solution than that in control group (Figure 1).

Catalase widely exists in the cell of microbes and plant, and it plays an essential role in nutrient transformation in soils. Catalase has a function of detoxification and stress resistance. It is one of critical enzymes in bio-defense system and attribute contributes to forming good environment [18]. In control group, Catalase activity reduced significantly during a short time in chlorpyrifos-polluted soils (Figure 1(II)). It was suggested that chlorpyrifos can obviously inhibit catalase activity, and catalase activity increased gradually with chlorpyrifos reducing naturally. Correlation analysis showed that Catalase activity was negatively correlated to chlorpyrifos $(P<0.05)$ (Table 2$)$. Catalase activity had an obviously increasing trend in soils treated with bacterial solution, and it keep increasing significantly from the $5^{\text {th }}$ day to the $15^{\text {th }}$ day after the treatment of bacteria $(P<0.05)$. Catalase activity had a significantly negative effect on chlorpyrifos in bacteria treated soils $(P<0.01)$ (Table 3$)$. It increased significantly for the reason that bacterial solution treatment led to the decreasing of chlorpyrifos content in soils at a short time. In return the inhibitory of catalase activity was weakened. And microbes grew, promoted emergency response and secreted a lot of catalases to resist toxic hazards. It was different from the relative study [19], in this study catalase activity was not only positively correlated to amylase activity in bacteria treated soils polluted by chlorpyrifos $(P<0.05)$ but also was positively correlated to $\mathrm{PH}(P<0.01)$ (Table 2$)$. After the treatment of bacterial solution the two significant correlations were kept, meanwhile catalase activity had a significantly positive correlation with available phosphorus.

Amylase is widespread among the living organisms, such as microbes and animals. It directly participates in the metabolic processes of organic matter in soil, and especially it is an indispensable enzyme in helping carbon cycle in nature [17, 18]. Amylase activity in soils sprayed with only chlorpyrifos reduced partially at a short time. This reflected an inhibitory effect of chlorpyrifos on amylase activity. Because organic matter increased and chlorpyrifos was degraded as Brassica junceai grew, amylase activity restored to the level of original gradually. It appeared an insignificantly negative between amylase and chlorpyrifos in Table $2(P>0.05)$. In the bacteria treated soils, chlorpyrifos was degraded and microbial activity increased, furtherly amylase activity increased significantly. From day 5 to day 15 , amylase activity enhanced significantly $(P<0.01)$ and had a significantly negative correlation with chlorpyrifos $(P<0.01)$.

Phosphatase plays an essential role in phosphorus cycle in soil. It can hydrolyze complex organic phosphorus into inorganic phosphorus which can be absorbed by living organisms. Then the restriction of the quantity of inorganic phosphorus is attenuated. Therefore, the degree of phosphatase activity is directly connected with phosphorus in soil [17]. As showed in the Figure 1 (IV), phosphatase activity decreased during a short period and increased gradually to original level until Brassica junceai was harvested. The correlation analysis demonstrated that phosphatase activity was negatively correlated to chlorpyrifos in soils without bacterial treatment, but the correlation was not significant $(P>$ 0.05 ) (Table 2). Phosphatase activity increased gradually in bacteria treated soils. And as the control group phosphatase activity showed insignificantly negative correlation with chlorpyrifos $(P>0.05)$. Meanwhile, phosphatase activity in bacterial solution treated soil samples became higher than that in the untreated soil samples in the different samples collected period, particularly on day 5 and day $15(P>0.05)$ (Table. 3$)$. After treating with microbes solution, the quantity of chlorpyrifos reduced in a short time after treating with bacteria. What's more, some died microbes were utilized directly or indirectly or even went into soils. All those will lead to the increasing of phosphatase activity [20-22].

Chlorpyrifos application will have a direct effect on soil enzymes, and the low-concentration chlorpyrifos can activate enzymes in soil for further transformation and utilization of $\mathrm{N}$, $\mathrm{P}$ and $\mathrm{K}$ and so on in soil [23]. But during a short period enzyme activity will decline. It may be the result that microorganisms are inhibited physiologically by chlorpyrifos, and their damaged cells structures go against the secretion of enzymes [24]. Once microbial resistance appears, microbes will start to secrete enzymes increasingly. Combined with enzymes released by died microbes, so the enzyme activities increase [25]. In the processes of soil remediation, the change of enzyme activities is due to a variety of factors, such as the concentration or the construction of contaminants, physical and chemical properties, and microbial metabolic activity and so on $[18,26]$. This study results can explain well that situation. In the control group, urease activity was slightly correlative with available phosphor in soils, while the positive correlation was improved in the bacteria treated soils. Meanwhile, the negative correlation between urease activity and available potassium was also increased in soils treated with bacteria. 

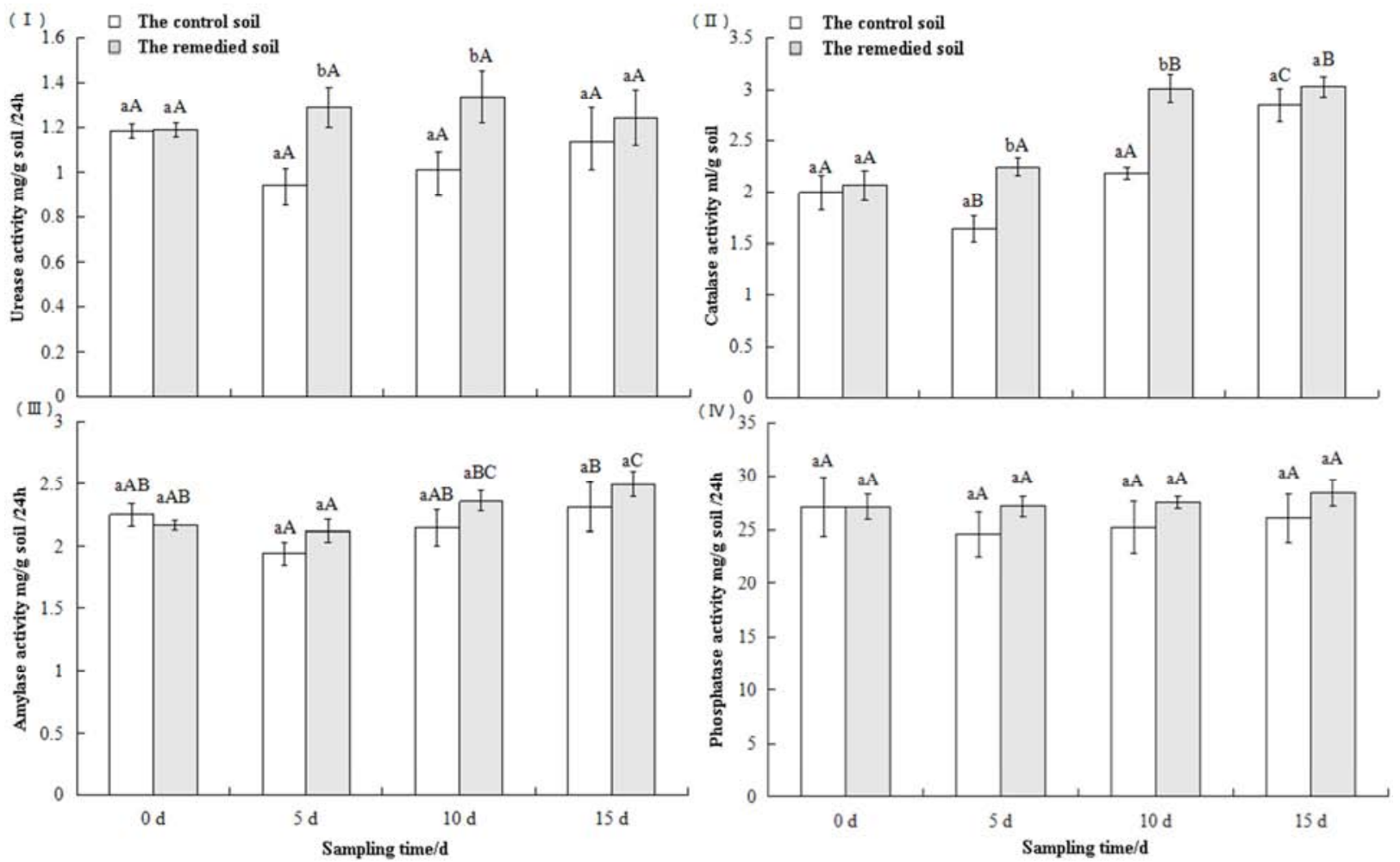

Figure 1. Soil enzyme activities at each sampling time.

Lowercase letters stand for differences between the remediated soil group and the control group at different time $(P<0.05)$. Capitals stand for differences in different groups at the same time $(P<0.05)$.

Table 2. Correlation analysis of enzyme activity, available nutrient and chlorpyrifos residue in chlorpyrifos-sprayed soils.

\begin{tabular}{|c|c|c|c|c|c|c|c|c|c|}
\hline & Time & Urease & Catalase & Amylase & Phosphatase & $\begin{array}{l}\text { Available } \\
\text { nitrogen }\end{array}$ & $\begin{array}{l}\text { Available } \\
\text { phosphorus }\end{array}$ & $\begin{array}{l}\text { Available } \\
\text { potassium }\end{array}$ & pH \\
\hline Urease & -0.076 & & & & & & & & \\
\hline Catalase & $0.764 * *$ & 0.378 & & & & & & & \\
\hline Amylase & 0.252 & $0.920 * *$ & $0.607^{*}$ & & & & & & \\
\hline Phosphatase & -0.124 & 0.400 & 0.161 & 0.381 & & & & & \\
\hline Available nitrogen & $-0.643^{*}$ & 0.341 & -0.477 & 0.068 & -0.051 & & & & \\
\hline Available phosphorus & $-0.620 *$ & 0.186 & -0.459 & -0.099 & 0.039 & 0.519 & & & \\
\hline Available potassium & -0.509 & -0.074 & -0.549 & -0.243 & 0.304 & 0.353 & 0.301 & & \\
\hline $\mathrm{pH}$ & $-0.847 * *$ & -0.288 & $-0.941 * *$ & -0.515 & 0.05 & 0.531 & 0.411 & $0.613^{*}$ & \\
\hline Chlorpyrifos & $-0.890 * *$ & -0.106 & $-0.660^{*}$ & -0.397 & 0.358 & 0.411 & 0.497 & 0.567 & $0.791 * *$ \\
\hline
\end{tabular}

$*, \mathrm{P}<0.05 ; * *, \mathrm{P}<0.01$.

Table 3. Correlation analysis of enzyme activity, available nutrient and chlorpyrifos residue in chlorpyrifos-sprayed and bacteria-treated soils.

\begin{tabular}{|c|c|c|c|c|c|c|c|c|c|}
\hline & Time & Urease & Catalase & Amylase & Phosphatase & $\begin{array}{l}\text { Available } \\
\text { nitrogen }\end{array}$ & $\begin{array}{l}\text { Available } \\
\text { phosphorus }\end{array}$ & $\begin{array}{l}\text { Available } \\
\text { potassium }\end{array}$ & $\mathbf{p H}$ \\
\hline Urease & 0.250 & & & & & & & & \\
\hline Catalase & $0.914 * *$ & 0.244 & & & & & & & \\
\hline Amylase & $0.829 * *$ & 0.130 & $0.857 * *$ & & & & & & \\
\hline Phosphatase & 0.491 & -0.227 & 0.484 & 0.495 & & & & & \\
\hline Available nitrogen & 0.543 & 0.381 & 0.542 & 0.469 & 0.216 & & & & \\
\hline Available phosphorus & $0.849^{* *}$ & 0.259 & $0.896^{* *}$ & $0.722 * *$ & 0.563 & 0.461 & & & \\
\hline Available potassium & -0.287 & 0.233 & -0.251 & -0.385 & -0.252 & 0.077 & -0.460 & & \\
\hline $\mathrm{pH}$ & $-0.945 * *$ & -0.36 & $-0.862 * *$ & $-0.810 * *$ & -0.384 & -0.551 & $-0.786 * *$ & 0.227 & \\
\hline Chlorpyrifos & $-0.998 * *$ & -0.242 & $-0.912 * *$ & $-0.840 * *$ & -0.503 & -0.51 & $-0.848 * *$ & 0.293 & $0.936^{* *}$ \\
\hline
\end{tabular}

$*, \mathrm{P}<0.05 ; * *, \mathrm{P}<0.01$. 


\subsection{Available Nutrient Change in Soils During Different Remediative Period}

Nitrogen in soils is a dispensable nutrient element for plants, and the concentration and supply of it in soils will directly affect the growing and development of plants. Available nitrogen, an essential indicator measuring the level of nitrogen, can reflect the dynamic change and the supply of nitrogen and furtherly indicate indirectly soil fertility status [27]. Figure 2 (I) showed that available nitrogen exhibited declining trend in only Chlorpyrifos treated soils with Brassica junceai growing. There was insignificantly positive correlation between available nitrogen and Chlorpyrifos $(P>0.05)$ (Figure $2(\mathrm{I})$ ). Because of the improving utilization of nutrient element by microbe activity and the degradation of Chlorpyrifos in bacteria treated soils, available nitrogen was enhanced and the transformational ability of nitrogen was improved to some extent after soil remediation by microbes. The concrete change for available nitrogen in in bacteria treated soils was showed as follow: it slightly declined from day o to day 5 . But there was a raising trend from day 5 to day 15 , especially from day 5 to day 10 it sharply increased, and the raising trend slowed down after the end of Brassica junceai growing. Based on the correlation analysis, available nitrogen presented a negative correlation with the quantity of Chlorpyrifos in soil after the treatment of bacteria.

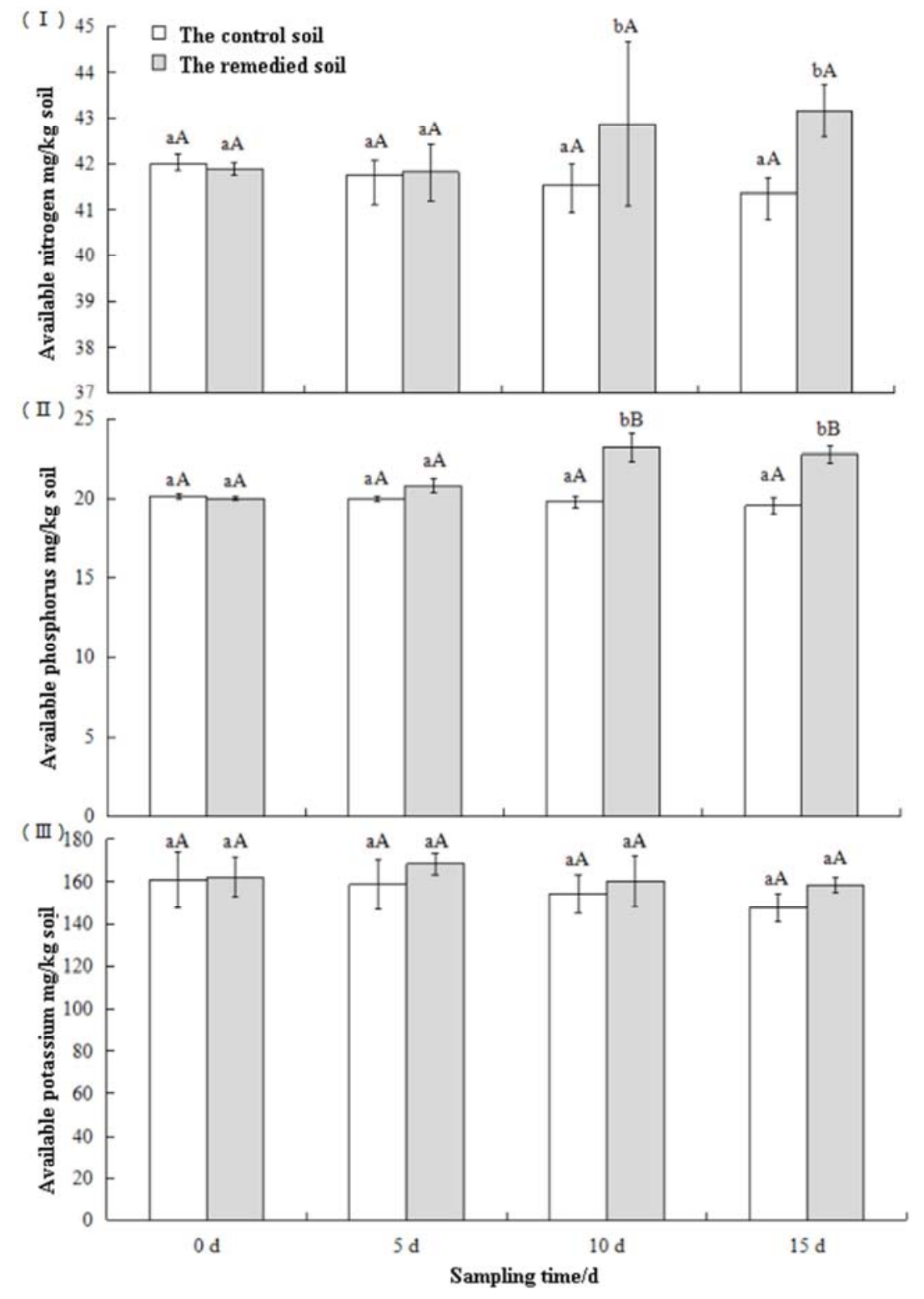

Figure 2. The available nutrients contents in the soil at each sampling time.

Lowercase letters stand for differences between the remediated soil group and the control group at different time $(P<0.05)$. Capitals stand for differences in different groups at the same time $(P<0.05)$. 
Available phosphorus is direct origin of phosphorus for plants, also one of main resources for nutrient, and even an important indicator of soil fertility [20] (Zheng et al. 2016). In the group treated only with Chlorpyrifos, available phosphorus slightly change with Brassica junceai growing, and was positively correlative with Chlorpyrifos but insignificantly $(\mathrm{P}>0.05)$ (Table 2). After treating soils with bacteria, available phosphorus exhibited increasing trend, and its raising amplitude was highest during day 5 and day 10 . The negative correlation between it and Chlorpyrifos was observed $(P<0.01)$ (Table 3$)$.

Available potassium can be absorbed by plants directly, and is a critical indicator reflecting the supply capability of soil potassium [28]. As Brassica junceai grew, the quantity of available potassium presented declining trend in only Chlorpyrifo-treated soils, and was positively correlative with the quantity of Chlorpyrifos in some degree $(P>0.05)$ (Table 2 ). The content of available potassium in soil firstly increased and then declined in bacteria-treated soils. The analysis of correlation demonstrated that its content was positively related to that of Chlorpyrifo $(P>0.05)$. In addition, compared with the only Chlorpyrifo-treated group, its content was all obviously higher at every sampling time, especially on day 5 $(P<0.05)$ (Figure 2).

The application of Chlorpyrifo will affect the stability of microbial communities functions and soil enzymatic activities [29], while the content of available nutrients in soil may have positive relationship with the number of microbes in soil [30]. Therefore, in only Chlorpyrifo-sprayed soils, available nutrients decrease to a certain degree, and its content show positive correlation with the quantity of Chlorpyrifo. Available nutrients, in bacteria treated soils that have sprayed with Chlorpyrifo, are higher than those in soils without bacterial treatment at every sampling time. Especially for available phosphorus in bacteria treated group, it obviously increases in the late phase comparing with the control group $(P<0.05)$ (Table 3$)$. The main reason is attributed to the reduction of Chlorpyrifo by microorganisms' utilization. On the one hand, that makes microorganisms growing and become more active. On the other hand, that also attenuates the inhibition on enzymes by Chlorpyrifo. So enzyme activities in soils are enhanced and furtherly the transformational ability of nutrient elements is improved in microbes-remediated soils.

\section{Conclusion}

The Chlorpyrifo emulsifiable concentrate $\left(60 \mathrm{~g} / \mathrm{hm}^{2}\right)$ has an effect on enzymatic activities and available nutrients in soils where Brassica juncea grows. It will inhibit the activities of urease, catalase, amylase and phosphatase during a short time, especially for catalase $(P<0.05)$. The correlation analysis indicates that $\mathrm{pH}$ is negatively correlative with catalase activity $(P<0.01)$ and positively related to available potassium $(P<0.05)$. In the Chlorpyrifo-polluted soils treated with bacterial solution $\left(5 \mathrm{~L} / \mathrm{hm}^{2}\right)$, enzymatic activities are improved especially for urease and catalase $(P<0.05)$. There are negative correlations both between catalase and Chlorpyrifo residue $(P<0.01)$ and between catalase and $\mathrm{pH}$ $(P<0.01)$. Besides, the contents of available nutrients, especially available nitrogen, are also increased. Available phosphorus has a negative correlation with both Chlorpyrifo residue and $\mathrm{pH}(P<0.01)$, but has a positive correlation with catalase $(P<0.01)$. In conclusion, micro-remediation can contribute to enhancing the contents of available nitrogen, available phosphatase and available potassium in soil and improve soil fertility well.

\section{Acknowledgements}

The study was supported by research grants from the National Natural Science Foundation of China (Nos. 31200474, 31270498 and 31500358) and Application and Foundation Key Project from Sichuan Department of Science and Technology of China (No. 2017JY0045).

\section{References}

[1] Xu G., Zheng W., Li Y., et al. Biodegradation of chlorpyrifos and 3,5,6-tricholoro-2-pyridinol by a newly isolated Paracoccus sp. strain TRP. Int Biodeter Biodegr, 2008, (62): 51-56.

[2] Randhanwa M. A., Anjum F. M., Ahmed A., et al. Field incurred chlorpyrifos and 3,5,6-trichloro-2-pyridinol residues in fresh and processed vegetables. Food Chem, 2007, (103): 1016-1023.

[3] Cai E. X. Residual dynamics and safety assessment of chlorpyrifos in banana and orchard soil. Journal of Safety and Environment, 2015, 15(4): 349-352.

[4] Zhang J. Y., Liu L. L., Li G. C., et al. Oxidative stress effects of chlorpyrifos on zebrafish embryos. China Environmental Science, 2016, 36(3): 927-934.

[5] Duan H. M. Factors influencing the biodegradation of chlorpyrifos by a Bacillus cereus strain. Journal of Safety and Environment, 2015, 15(2): 174-177.

[6] Yang Z. H., Wu R. P., Wang B., et al. Bioremediation of Cr (VI) contaminated soil and pilot study. Environmental Chemistry, 2013, 32(9): 1758-1765.

[7] Yao X. H., Min H., Lu Z. H., et al. Influence of acetamiprid on soil enzymatic activities and respiration. European Journal of Soil Biology, 2006, 42(2): 120-126.

[8] Yang W. B., Geng Y. Q., Wang D. M. The activities of soil enzyme under different vegetation types in Li river riparian ecotones. Acta Ecologica Sinica, 2015, 35(14): 1-12.

[9] Huang C. Y. Soil sciences. Beijing: China Agricultural Press, 2000 .

[10] Luo F. Z. Xiang L., Li H., et al. Effects of arbuscular mycorrhizal fungi (AMF) on growth and Cd accumulation of upland rice and soil enzyme activities in cadmium contaminated soil. Journal of Agro-Environment Science, 2015, 34(6): 1090-1095. 
[11] Cai Z. Q., Li S. S., Zhang W. S. Effects of the novel pyrimidynyl oxybenzoic herb-icide ZJ0273 on enzyme activities, microorganisms and its degradation in Chinese soils. Environmental Science and Pollution Research, 2015, 22(6): $4425-4433$.

[12] Thomas P., Markus D. M., Hans R. B., et al. Environmental behavior of the chiral herbicide haloxyfop. 1 rapid and preferential interconversion of the enantiomers in soil. J. Agric. Food Chem., 2015, 63(10): 2583-2590.

[13] Huang C. P., LI J., LI Y. L., et al. Effect of applying Bacillus subtilis MZS1 strain on degradation of chlorpyrifos residue in Brassica juncea and soil. Guizhou Agricultural Sciences, 2016, 44(4): 66-70.

[14] Luo M., Chen X., Shu P., et al. Simultaneous determination of indoxacarb and chlorpyrifos residues in Brassica oleracea by high performance liquid chromatography. Journal of Mountain Agriculture and Biology, 2014, 33(1): 5-7.

[15] Zheng H. Y., Zhang D. S. Dynamic biochemical study of soil. Beijing: China Science Press, 1982.

[16] Bao S. D. Soil Agricultural and Chemicals Analysis Method. Beijing: China Agriculture Press, 2000.

[17] Zhao Z. Q., Hou X. W., Li Q. F., et al. Effects of chlorpyrifos and carbosulfan on soil enzymes activity in banana rhizosphere Journal of Agro-Environment Science, 2010, 29, 100-101.

[18] Wang H. J., Zhu N. W., Yang C., et al. Effect of soil enzyme activities during bioremediation of crude oil-contaminated soil. Journal of Agro-Environment Science, 2013, 32(6): 1178-1184.

[19] Dai W., Bai H. Y. Correlations of soil catalase activity and it's kinetic characteristic with some soil properties. Journal of Beijing Forestry University, 1995, 17(9): 37-41.

[20] Zheng X. B., Fan J. B., Zhou J., et al. Effects of combined application of biogas slurry and chemical fertilizer on soil nutrients and peanut yield in upland red soil. Acta Pedologica Sinica, 2016, 53(3): 675-684.
[21] Zheng M. H., Huang J., Chen H., et al. Effects of nitrogen and phosphorus addition on soil phosphatase activity in different forest types. Acta Ecologica Sinica, 2015, 35(20): 6703-6710 (in Chinese).

[22] Nannipieri P., Giagnoni L., Landi L., et al. Role of phosphatase enzymes in soil // Phosphorus in Action. Berlin Heidelberg: Springer, 2011.

[23] Wu X. H., Xu J., Dong F. S., et al. Effects of five herbicides on activities of soil invertase and urease. Chinese Journal of Pesticide Science, 2015, 17(2): 179-184.

[24] Shan M., Fang H., Wang X., et al. Effect of chlorpyrifos on soil microbial populations and enzyme activities. Journal of Environmental Sciences, 2006, 18(1): 4-5.

[25] Wang L. M., Xu D. M., Chen B., et al. Effects of external contaminants on soil phosphatase. Techniques and Equipment for Environmental Pollution Control, 2004, 5(5): 11-17.

[26] Zeng Q. B., Li T., Wang C. Q., et al. Microbial Agents: Effects on Activities of Urease and Catalase in Flue-cured Tobacco Rhizosphere Soil. Chinese Agricultural Science Bulletin, 2016, 32(22): 46-50.

[27] Li H., Chen Y. X., Liang X. Q., et al. Influence of soil urease activities on nitrogen conversion in floodwater in paddy field. Journal of Soil and Water Conservation, 2015, 20(1): 55-58.

[28] Chen Q. C., Xu F, L., Wang W. L., et al. Seasonal dynamics of available $\mathrm{K}$ in soil for different ages of Larix principis-rupprechtii in the northern foot of the Qinling. Journal of Plant Nutrition and Fertilizer, 2014, 20(5): 1243-1249.

[29] John E. M., Shaike J. M. Chlorpyrifos: Pollution and remediation. Environmental Chemistry Letters, 2015, 13(3): 269-291.

[30] Zhang L. H., Li K., Hu X. X., et al. Effect of microbial agents on the available nutrient and enzyme activity of grape replant soil. Northern Horticulture, 2015, (4): 162-164. 